\title{
Application of Bethesda Reporting System of Thyroid Cytology and Its Clinical Significance
}

\author{
Dr. Pooja Shrivastava*, Dr. Farah Jalaly Meenai \\ Chirayu Medical College and Hospital, Bairagarh Bhopal, Madhya Pradesh, India
}

DOI: $\underline{10.36348 / \text { sjpm.2020.v05i05.007 }}$

| Received: 29.04.2020 | Accepted: 10.05.2020 | Published: 17.05.2020

*Corresponding author: Dr. Pooja Shrivastava

\section{Abstract}

Final diagnosis of thyroid lesions requires morphological examination for which FNAC and histopathological examination become mandatory tests. In our study preoperative FNAC on 100 patients and along these histopathology reports of 22 patients were correlated and conclusions drawn after statistical analysis. Results: Diagnostic categorization of FNACs based on Bethesda classification showed that of the benign lesions (category 2), 45were Nodular colloid, 13Hashimoto thyroiditis, 13 multinodular goitre, 3Primary hyperplasia and 2 Hyperplastic nodule 1 was of de-quervans thyroiditis, 1 was of adenomatous goitre. Of the 12 malignant lesions (category 6), 7 were papillary carcinoma, 2anaplastic carcinoma, 1medullary carcinoma, 2 metastatic carcinoma on FNAC, 8 were suspicious for follicular neoplasm (category 4) and 1 was of follicular lesion of undetermined significance on FNAC (category 3). Among 100 cases, 22 were biopsied and subjected to histopathology. 11cases were benign. Out of these, 2 were of colloid goitre, 3follicular adenoma, 3multinodular goitre 2 was of hasimoto's, 1 was of thyroglossal cyst. 11 cases were malignant, Out of these, 6 were papillary carcinoma, 3 were Follicular carcinoma and 1 medullary carcinoma 1 case of noninvasive follicular thyroid neoplasm with papillary like nuclear features. Out of 22 cases examined hitopathologically findings were similar to FNAC in 21 cases and findings differed in 1 case. The sensitivity \& specificity for FNAC of thyroid neoplasm in present study were $82.6,95.2 \%$, respectively. Conclusions: FNAC is simple, safe \& cost effective modality in investigation of thyroid swellings with high accuracy. The bethesda system of reporting has high concordance with the histopathological findings.

Keywords: Thyroid swelling, FNAC thyroid, Bethesda system of thyroid cytology, histopathology, papillary carcinoma, colloid goitre.

\footnotetext{
Copyright @ 2020: This is an open-access article distributed under the terms of the Creative Commons Attribution license which permits unrestricted use, distribution, and reproduction in any medium for non-commercial use (NonCommercial, or CC-BY-NC) provided the original author and sources are credited.
}

\section{INTRODUCTION}

Thyroid lesions are among the most common clinical conditions. The prevalence of the thyroid nodules ranges from $4 \%$ to $10 \%$ in the general adult population and from $0.2 \%$ to $1.2 \%$ in children [1]. It is estimated $4-7 \%$ adults have palpable enlargement of thyroid and 10 times more have impalpable nodules. Most of them are benign and fewer than 5\% are actually malignant [2]. In India, thyroid cancer comprises approximately $1 \%$ of all head and neck cancers.

A multitude of diagnostic tests like clinical method (T3,T4,TSH), palpation method, ultrasonography, fine needle aspiration cytology are available to evaluate thyroid swelling. Final diagnosis requires morphological examination of lesions for which FNAC and histopathological examination become mandatory tests [3].
FNAC examination has proved to be a method for the preoperative diagnosis of benign and malignant thyroid nodules [4].

Direct FNAC and guided FNAC is a diagnostic tool in which cells are aspirated from a palpable and non-palpable swelling using syringe and fine needle. It is a simple, accurate, safe and cost effective minimally traumatic; it is ideal first line rapid diagnostic technique.

\section{AIMS AND OBJECTIVES}

The aims and objectives for the study are:-

1. Application of the Bethesda category for FNAC and correlate the results with final histopathological diagnosis in which ever cases possible 
2. To observe the spectrum of thyroid lesions, their incidences, frequencies, age distribution and occurrence.

3. To study the cytomorphological features in various benign and malignant thyroid lesions on fine needle aspiration cytology and to provide accurate diagnosis.

4. To correlate the finding of FNAC of thyroid lesions with USG thyroid and estimates the concordance and discordance between two modalities.

\section{MATERIAL AND METHODS}

The study was undertaken in the Department of Pathology, Chirayu Medical College and Hospital, Bhopal during the period from june 2017 to june 2019.

The study comprised of 103 patients who presented with the history of swelling of thyroid.
The patients were selected consecutively as and when they presented during the study periods considering inclusion and exclusions criterias. The selected patients were subjected to clinical examinations, thyroid function test ultrasonography scans and FNAC and histopathological examination of the thyroidectomy specimen in whichever cases possible.

\section{Inclusion Creteria}

1. Cases of thyroid swelling which move with the deglutition included in the study.

2. Cases of thyroid lesions detected on imaging subjected to further evaluation by FNA.

\section{Exclusion Creteria}

1. Neck swellings due to any other pathology like lymphadenopathy.

2. Critically ill patient.

3. Non co-operative patients.

The cytology reporting has been done by following reporting system:

The Bethesda for Reporting Thyroid cytopathology: Recommended Diagnostic Categories

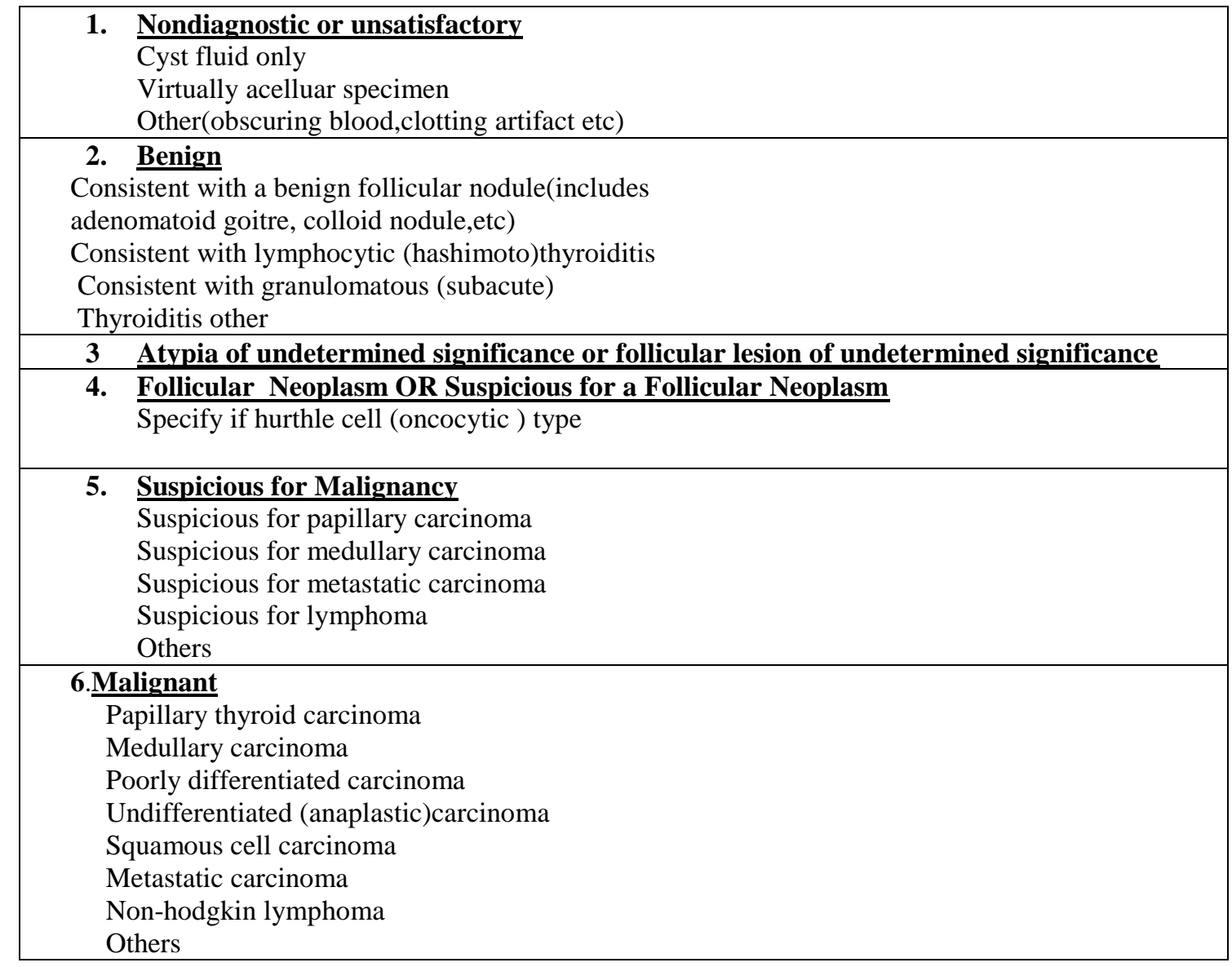

Thyroid ultrasound examination was performed with a real-time instrument using a $7.5 \mathrm{mHz}$ linear transducer in the Radiology Department of chirayu medical college and Hospital.
All the patients were clinically examined in detail according to the proforma and a careful palpation of the thyroid gland was done to judge precisely the location for aspiration. After brief explanation about the procedure to the patient, aspiration was done with the 
patient in supine or sitting position with extended neck, so as to make the thyroid swelling appear prominent.

Under aseptic precautions 23 gauge needle with a $10 \mathrm{ml}$ disposable plastic syringe was inserted into the lesion and to and fro movements performed quickly. Under negative pressure material gets collected in the needle, after collection of material negative pressure was released, needle with syringe holder was removed, the material was spread over a clean labelled slide and smears were prepared.

The air dried and 95\% alcohol fixed smears were prepared for giemsa, papanicolaou stains respectively. Whenever fluid was obtained all the contents were aspirated and centrifuged, smears were made from the sediment and stained by the stains as described above.

When the surgery was done, the received specimens were fixed with $10 \%$ formalin and detailed gross examination was done and sections were taken from the representative areas for paraffin sections and stained by $\mathrm{H} \& \mathrm{E}$. The sections were studied under light microscopy.

Cytological diagnosis was correlated with histopathology where ever cases possible.

\section{RESULTS}

The present study deals with the fine needle aspiration cytology (FNAC) of thyroid leisons and its clinico-pathological correlation. During the period of this study from june 2017 to june 2019, 103 ultrasonography and FNACs were performed out of which 22 cases were biopsied subsequently and subjected to histopathological study

\section{Age and gender distribution}

Age group of patient referred for thyroid aspiration ranged from 0 to 100 years with mean age of 42.14 .

In the present study, it has been observed that the incidence of thyroid lesions were more in the age group of 21-40yrs with 51cases $(49.5 \%)$, and least common in the age group of $81-100 \mathrm{yrs}$ with 1 case $(0.9 \%)$. The mean age is 42.14 yrs. The youngest patient was $10 \mathrm{yrs}$ male and oldest was $83 \mathrm{yrs}$ female

Majority of the patients were female accounting for $79 \%$, forming male to female ratio of $1: 3.68$.

\section{TSH LEVELS}

Table-1: TSH STATUS

\begin{tabular}{|l|l|l|}
\hline TSH status & No of cases & \% \\
\hline Euthyroid & 91 & 89 \\
\hline Hypo & 7 & 6 \\
\hline Hyper & 5 & 5 \\
\hline Total & 103 & 100 \\
\hline
\end{tabular}

In the present study, it has been observed that Out of 103 cases, maximum no. of cases was euthyroid (89\%), followed by hypothyroid (6\%) and $5 \%$ hyperthyroid.

\section{Incidences of benign and malignant lesions on USG}

Table-2: Incidences of benign and malignant_lesions of thyroid on USG findings

\begin{tabular}{|l|l|}
\hline Types of finding & Frequency \\
\hline Benign & 82 \\
\hline Malignant & 12 \\
\hline Suspicious & 9 \\
\hline TOTAL & 103 \\
\hline
\end{tabular}

In the present study, it has been observed that among the total thyroid lesion (103) USG, 82 were benign, 12 were malignant and 9 were suspicious.

\section{Distribution of cases}

Table-3: Cytological diagnosis of thyroid lesion $(\mathbf{n}=\mathbf{1 0 0})$

\begin{tabular}{|l|l|l|}
\hline Thyroid lesion of FNAC & $\begin{array}{l}\text { No. of } \\
\text { cases }\end{array}$ & $\begin{array}{l}\text { Bethesda } \\
\text { category }\end{array}$ \\
\hline Nodular colloid & 57 & 2 \\
\hline Hasimoto thyroiditis & 13 & 2 \\
\hline Grave's disease & 3 & 2 \\
\hline De-quervans & 1 & 2 \\
\hline Adenomatous goiter & 1 & 2 \\
\hline Follicular neoplasm & 8 & 4 \\
\hline $\begin{array}{l}\text { Papillary thyroid } \\
\text { carcinoma }\end{array}$ & 9 & 6 \\
\hline Medullary carcinoma & 2 & 6 \\
\hline Metastatic carcinoma & 2 & 6 \\
\hline $\begin{array}{l}\text { Follicular lesion of } \\
\text { undeternimed } \\
\text { significance }\end{array}$ & 1 & 3 \\
\hline Anaplastic carcinoma & 2 & 6 \\
\hline Thyroglossal cyst & 1 & - \\
\hline Total & 100 & \\
\hline
\end{tabular}

Total 100 cases diagonised by FNAC, out of which 57 cases were nodular colloid (colloid goitre, mutli nodular goiter, colloid nodule), 13 cases were thyroiditis , 3 cases were grave's diseases , 1 case dequervans thyroiditis, 1 adenomatous goiter, 1 thyroglossal cyst, 8 were follicular neoplasm(suspicious for malognancy), 1 follicular cell of insignificant determined(suspicious for malignancy), 9 cases of papillary carcinoma , 2 were anaplastic carcinoma, 2 medullary carcinoma and 2 were metastatic carcinoma 


\section{Sonography and cytology correlation}

Table-4: sonography and cytology correlation

\begin{tabular}{|l|l|l|l|l|}
\hline Broad diagnosis on USG & $\begin{array}{l}\text { No of cases } \\
\text { On sonography }\end{array}$ & No. of cases on FNAC & Correlated & Non correlated \\
\hline Benign & 79 & 77 & 77 & 2 \\
\hline Malignant & 12 & $14(12+2)$ & 12 & 0 \\
\hline Suspicious & 9 & 9 & 9 & 0 \\
\hline Total & 100 & 100 & 98 & 02 \\
\hline
\end{tabular}

Out of 100 cases, 79were broadly diagnosed on USG as benign pathologies however, among these cases FNAC suggested benign pathology of 77 cases and 2 cases were diagnosed on as malignant pathology. On FNAC one of these cases were diagnosed as papillary carcinoma and one of these diagnosed as medullary carcinoma.

12 cases given as malignant on USG, all 12 malignant cases turned out to be malignant on cytology, giving accuracy of malignant cases $100 \%$.
9 cases which were given as suspicious to malignant, 8 cases were turned out to be suspicious to follicular neoplasm on FNAC and 1 case which was given as suspicious for malignancy was turned out to be follicular lesion of undetermined significance.

\section{Histopathological Diagnosis of the Lesions}

In the present study of 100 cases, 22 patients underwent surgery and the histopathological diagnosis of the cases are given below

Benign lesions -11

Malignant lesions -11

Table-5: Histological diagnosis of thyroid leisons $(n=22)$

\begin{tabular}{|l|l|l|}
\hline Thyroid lesion on histopathology & No. of cases & Percentage \\
\hline Colloid goiter & 2 & 9 \\
\hline Hasimoto's thyroiditis & 2 & 9 \\
\hline Multinodular goiter & 3 & 13.6 \\
\hline Thyroglossal cyst & 1 & 4.6 \\
\hline Follicular adenoma & 3 & 13.6 \\
\hline Follicular carcinoma & 3 & 13.6 \\
\hline Papillary carcinoma & 6 & 27.4 \\
\hline Medullary carcinoma & 1 & 4.6 \\
\hline Nift & 1 & 4.6 \\
\hline Total & 22 & 100 \\
\hline
\end{tabular}

\section{Cytology-histopathology correlation of leisons}

Table-6: cytology-histopathology correlation

\begin{tabular}{|l|l|l|l|l|}
\hline Cytological diagnosis & no. of cases & Histopath diagnosis available & Co related with histopath & not correlated \\
\hline$\underline{B e n i g n}$ & $\underline{76}$ & $\underline{8}$ & $\underline{7(87.5 \%)}$ & $\underline{1(12.5 \%)}$ \\
\hline Nodular colloid goiter & 57 & 5 & $4(80 \%)$ & $1(20 \%)$ \\
\hline Hashimoto thyroiditis & 13 & 2 & $2(100 \%)$ & \\
\hline Grave's disease & 3 & 0 & & \\
\hline De-quervans & 1 & 0 & & \\
\hline Adenomatous goiter & 1 & 0 & & \\
\hline
\end{tabular}

\begin{tabular}{|l|l|l|l|l|}
\hline Thyroglossal cyst & 1 & 1 & $1(100 \%)$ & \\
\hline Malignant & $\underline{15}$ & $\underline{8}$ & $\underline{8}$ & $\underline{0}$ \\
\hline Papillary thyroid carcinoma & 9 & 6 & $6(100 \%)$ & \\
\hline Medullary carcinoma & 2 & 1 & $1(100 \%)$ & \\
\hline Metastatic & 2 & 0 & & \\
\hline Anaplastic & 2 & 0 & & \\
\hline NIFTP & 0 & 1 & $1(100 \%)$ & \\
\hline Atypia with undetermined significance & 1 & 0 & & \\
\hline Suspicious for Neoplasm & $\underline{8}$ & $\underline{6}$ & $\underline{6}$ & $\underline{0}$ \\
\hline Folicular neoplasm & 8 & 6 & $6(100 \%)$ & \\
\hline
\end{tabular}


Out of 100 adequate cases on FNAC, histopathology was available in 22 cases .out of 22 cases, 21(95.4\%) cases were confirmed on histopathology and 1 case was diagnosed as colloid nodule with cystic degeneration on fnac which was turned out to be papillary carcinoma on histopathology. Out of 22 cases, 11 were benign and 11 were malignant.

Present study showed 90\%specificity, $72.7 \%$ sensitivity for benign lesions while for malignant lesions; it was $100 \%$ specificity,

Table-7: Statistical Values for Benign and Malignant Lesions Calculated by Galen and Gambino's Methord

\begin{tabular}{|l|l|l|l|}
\hline SL.No. & Statistical index & Benign lesions & Malignant lesions \\
\hline 1 & Sensitivity & $72.7 \%$ & $91.6 \%$ \\
\hline 2 & Specificity & $90.9 \%$ & $100 \%$ \\
\hline 3. & Positive predicted value & $88.8 \%$ & $100 \%$ \\
\hline 4 & Negative predicted value & $76.9 \%$ & $90.9 \%$ \\
\hline
\end{tabular}

Case images

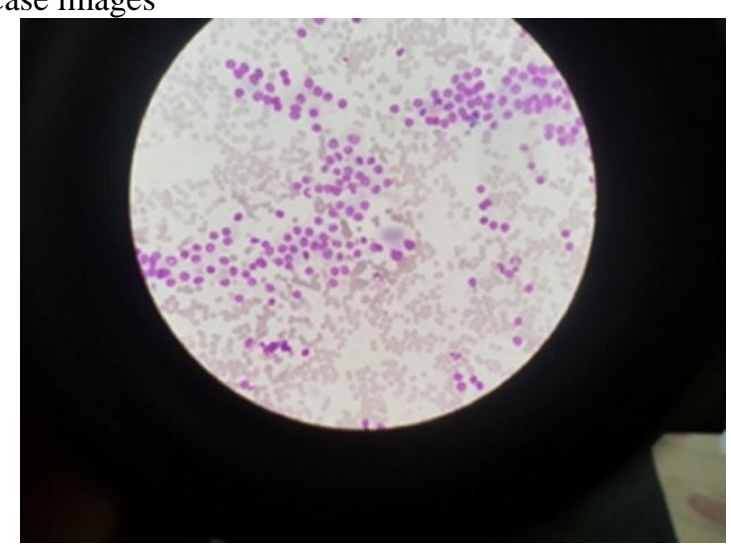

Image-1: FNAC showing papillary cluster showing powdery chromatin and intranuclear inclusion in papillary carcinoma Giemsa 400X

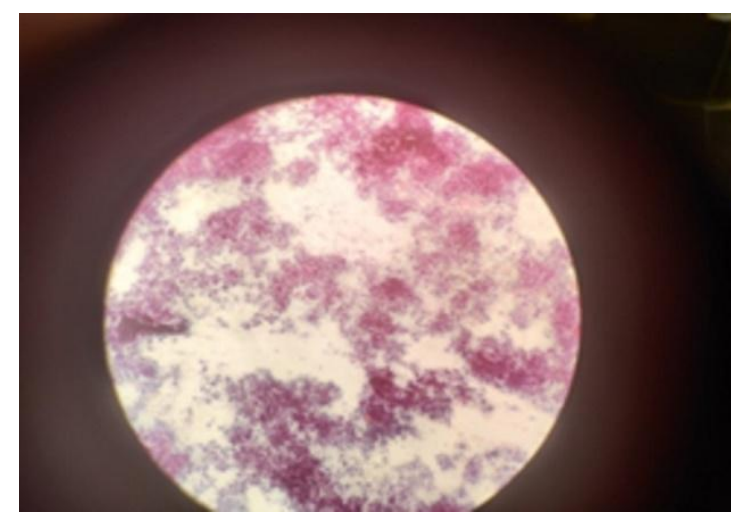

Image-2: FNAC of Anaplastic carcinoma 100X

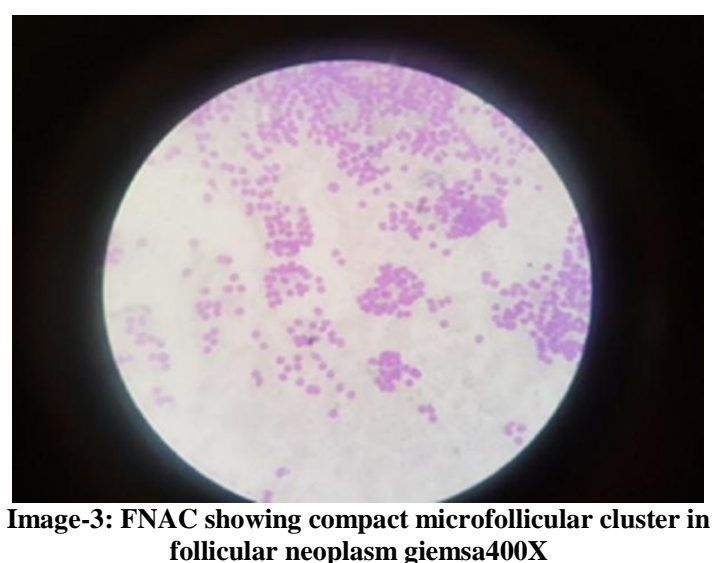

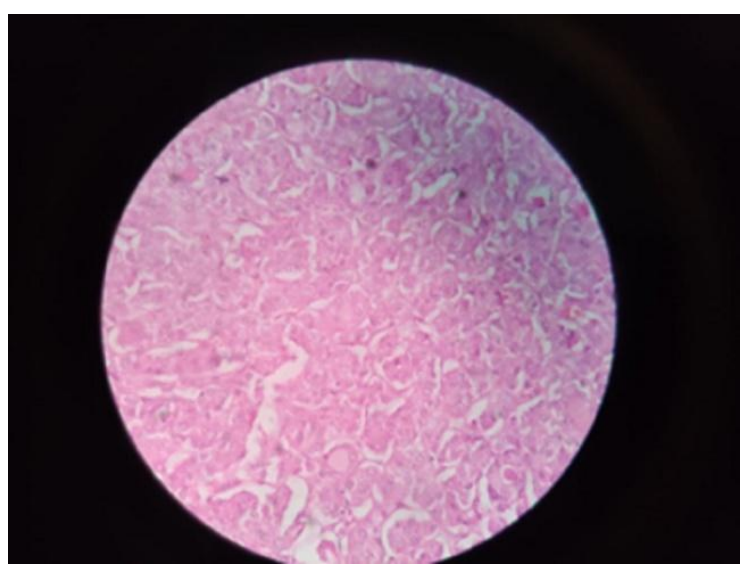

Image-4: Histopathology of follicular variant of papillary carcinoma H\&E 400X

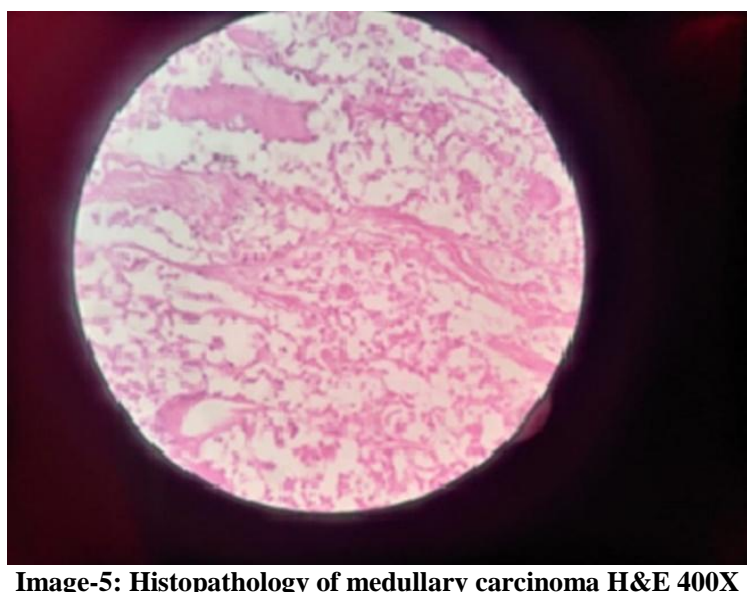

\section{DISCUSSION}

1. FNAC was performed on 103 cases for cytological evaluation.

2. Age range of the patients taken for the study was from 0- $100 \mathrm{yrs}$ with a mean age of 42.32yrs. According to our study 51cases $(49.5 \%)$ belonged to 21-40yrs of age which indicated higher incidence of thyroid lesions in 21-40 yrs of age. The youngest patient was 10yrs male and oldest was $85 y$ rs female.

3. Majority of the patients were females in the present study with 81 females and 22 males, with a age ratio of 1:6.5 respectively. 
4. On FNAC Out of the 103 cases of thyroid lesions,
A. 79 were benign lesions( Bethesda category 2)
B. 12 were malignant lesions (Bethesda category 6)
C. 8 were suspicious for follicular neoplasm(Bethesda category 4)
D. 1 was follicular lesion of undetermined significance (bethesda category 3 )
E. 3 samples were found inadequate for evaluation.( Bethesda category 1 )

5. Out of the79 benign lesions ( Bethesda category 2), 45 were Nodular colloid goiter, 13 Hashimoto thyroiditis, 13 multinodular goitre, 3 Primary hyperplasia and 2 Hyperplastic nodule 1 was of dequervans thyroiditis, 1 was of adenomatous goitre.

6. Out of the 12 lesions, 7 were Papillary carcinoma, 2 anaplastic carcinoma, 1 medullary carcinoma, 2 metastatic carcinoma.

7. On FNAC, 8 were suspicious for follicular neoplasm

8. 1 was of follicular lesion of undetermined significance (bethesda category 3 ).

9. Among 100 cases, 22 were biopsied subsequently and subjected to histopathological study.(Table 6)

A. Among these cases 8 were initially diagnosed as Benign on FNAC, out of which findings of 7 correlated with the histopathology. 1 which was diagnosed as Colloid cyst on FNAC turned out to be papillary carcinoma.

B. There were 8 cases which were diagnosed as malignant on FNAC and findings of all these cases correlated with histopathology indicating significant concordance.

C. There were 6 cases which categorised as suspicious for follicular neoplasm on FNAC, findings of all these 6 cases correlated with histopathology (3 were diagnosed as follicular adenoma and 3 as follicular carcinoma).

10. The diagnostic accuracy of benign and malignant lesions is $95.7 \%$ and $90 \%$ respectively

11. The sensitivity, specificity,positive predictive value and negative predictive value for FNAC of thyroid neoplasm in the present study are $77 \%, 98.3 \%, 87.5 \%$ and $96.7 \%$ respectively.

12. The overall diagnostic accuracy of FNAC for thyroid lesions is $95.7 \%$

The comparison of various parameters in our present study was done with that of studies by other authors.

Table-8: Age range in different studies in comparison with present study

\begin{tabular}{|c|c|c|}
\hline Study & Age range(years) & Mean age (years) \\
\hline Burch HB [1].(1996) & $15-83$ & 51.1 \\
\hline Aravinthan [5](2007) & $26-59$ & 46 \\
\hline Present study & $0-100$ & 42.14 \\
\hline
\end{tabular}

In the present study of 103 patients, the youngest patient was 10 years (patient with cytological diagnosis of thyroglossal cyst). The oldest patient was of 83 years with cytological diagnosis of nodular colloid goiter. The mean age of the patients was 42.14 yrs age group is similar to the study of Aravinthan as seen above.

Table-9: Comparision of Sex distribution and Male and Female ratio of with present study

\begin{tabular}{|l|c|c|c|c|}
\hline \multicolumn{1}{|c|}{ Study } & $\begin{array}{l}\text { Total } \\
\text { cases }\end{array}$ & Male & Female & M : F \\
\hline $\begin{array}{l}\text { Burch HB .[1] } \\
(1996)\end{array}$ & 422 & 91 & 331 & $1: 3.6$ \\
\hline Present study & 103 & 22 & 81 & $1: 3.6$ \\
\hline
\end{tabular}

In the present study of 103 cases, majority were females with 81 cases and 22 males with a male to female ratio of 1:3.68, which correlates well with the study of Burch HB et al.

Table-10: Comparison of TSH levels with different studies

\begin{tabular}{|c|c|c|c|c|}
\hline \multirow[t]{2}{*}{ Study } & \multirow{2}{*}{$\begin{array}{l}\text { Total cases } \\
\text { in which } \\
\text { TFTs done }\end{array}$} & \multicolumn{3}{|c|}{ Functional thyroid status in \% } \\
\hline & & Euthyroid & Hyperthyroid & Hypothyroid \\
\hline $\begin{array}{l}\text { Godinho- } \\
\text { Matos } \\
\text { L[6](1992) }\end{array}$ & 144 & 88 & 9 & 3 \\
\hline $\begin{array}{l}\text { Present } \\
\text { study }\end{array}$ & 103 & 89 & 5 & 6 \\
\hline
\end{tabular}


In present study, total no cases were 103 , out of which $89 \%$ of euthyroid, $5 \%$ of hyperthyroid and 6
$\%$ of were hypothyroid which is more or less consistent with Godinho-Matos L

Table-11: Comparative incidences of benign and malignant lesions on FNAC in different studies

\begin{tabular}{|l|l|l|l|}
\hline Study & Benign & Malignant & Ratio \\
\hline Silverman JF [7](1986) & 228 & 80 & $1: 2.9$ \\
\hline Present study & 76 & 15 & $1: 5$ \\
\hline
\end{tabular}

In the present study of 103 cases, 76 were benign and 15 were malignant, 9 were suspicious and 3 were inadequate, with a ratio of 1:5 which is consistent with the study Silverman JF.

Table-12: Comparative study of different benign lesions on FNAC

\begin{tabular}{|l|l|l|l|}
\hline Study & $\begin{array}{l}\text { Nodular } \\
\text { colloid } \\
\text { goitre }\end{array}$ & $\begin{array}{l}\text { Hashimoto } \\
\text { Thyroiditis }\end{array}$ & $\begin{array}{l}\text { Primary } \\
\text { hyperplasia }\end{array}$ \\
\hline Silverman JF .[7](1986) & $156(52.8 \%)$ & $3(1.0 \%)$ & $5(1.6 \%)$ \\
\hline Hawkins F [8].(1989) & $885(63.2 \%)$ & $611(43.6 \%)$ & $40(2.8 \%)$ \\
\hline Present study & $57(57 \%)$ & $13(13 \%)$ & $3(3 \%)$ \\
\hline
\end{tabular}

Hence findings of the present study are similar to the above mention studies if compared on the basis of percentage of various benign lesions found in the studies.

Table-13: Comparison of malignant lesions on FNAC in different studies

\begin{tabular}{|l|l|l|l|}
\hline \multirow{2}{*}{ Study } & \multicolumn{3}{|c|}{ FNAC } \\
\cline { 2 - 4 } & $\begin{array}{l}\text { Follicular } \\
\text { neoplasm }\end{array}$ & $\begin{array}{l}\text { Papillary } \\
\text { carcinoma }\end{array}$ & $\begin{array}{l}\text { Medullary } \\
\text { carcinoma }\end{array}$ \\
\hline $\begin{array}{l}\text { Hawkins F } \\
{[8](1989)}\end{array}$ & 52 & 50 & - \\
\hline Present study & 8 & 9 & 1 \\
\hline
\end{tabular}

In the present study, 8 cases were of follicular neoplasm,9 cases were papillary carcinoma and 1 case was of medullary carcinoma hence the present study is similar to Hawkins F

Table-14: comparative study of Diagnostic Accuracy of Papillary Carcinoma

\begin{tabular}{|l|l|l|l|}
\hline Study & FNAC diagnosis & $\begin{array}{l}\text { Histopathology } \\
\text { Diagnosis }\end{array}$ & $\begin{array}{l}\text { Accuracy } \\
\%\end{array}$ \\
\hline Hall TL [9](1989) & 29 & 26 & 89.6 \\
\hline $\begin{array}{l}\text { Gagneten CB [10] } \\
(1987)\end{array}$ & 4 & 5 & 80 \\
\hline Present study & 6 & 7 & 85.7 \\
\hline
\end{tabular}

In the present study, 6 cases of papillary carcinoma on FNAC were confirmed with histopathology. 1 case which was diagnosed as Colloid nodule with cystic degenration on FNAC turned out to be papillary carcinoma and its variants. The accuracy of FNAC was $85.7 \%$ which is comparable with the study of Hall TL

Table-15: comparative study of Diagnostic Accuracy of Follicular neoplasm

\begin{tabular}{|l|l|l|l|}
\hline Study & FNAC diagnosis & $\begin{array}{l}\text { Histopathology } \\
\text { Diagnosis }\end{array}$ & $\begin{array}{l}\text { Accuracy } \\
\%\end{array}$ \\
\hline Silverman JF [7](1986) & 27 & 36 & 75 \\
\hline Present study & 6 & 6 & 100 \\
\hline
\end{tabular}

In the present study, of the 6 cases of Follicular neoplasm on FNAC, 3 cases were of Follicular adenoma on histopathology and the other 3 cases turned out to be follicular carcinoma on histopathology, giving a diagnostic accuracy of $100 \%$ which is more consistent with the study of Silverman JF. 


\section{Comparision of statistical data}

Table-16: Comparison of Statistical data

\begin{tabular}{|l|l|l|l|}
\hline \multicolumn{1}{|c|}{ Study } & \multicolumn{1}{c|}{ Sensitivity } & \multicolumn{1}{c|}{ Specificity } & \multicolumn{1}{c|}{ Accuracy } \\
\hline $\begin{array}{l}\text { Silverman JF } \\
\text { [7]1986) }\end{array}$ & $93 \%$ & $95.1 \%$ & $94 \%$ \\
\hline $\begin{array}{l}\text { Hawkins F .[8] } \\
(1987)\end{array}$ & $86.3 \%$ & $95.3 \%$ & $93.7 \%$ \\
\hline $\begin{array}{l}\text { Burch HB } \\
{[1](1996)}\end{array}$ & $80 \%$ & $73.2 \%$ & $75.2 \%$ \\
\hline Present study & $82.6 \%$ & $95.2 \%$ & $97.5 \%$ \\
\hline
\end{tabular}

In the present study sensitivity is $82.6 \%$, specificity $95.2 \%$, positive predictive value $95 \%$, negative predictive value $83.3 \%$, and diagnostic accuracy of $97.5 \%$, which are consistent with the study of Hawkins F (1987)with a sensitivity of $86.3 \%$, specificity of $95.3 \%$ and diagnostic accuracy of $93.7 \%$

\section{CONCLUSION}

In our study we re-emphaize the importance of the bethesda system and we have found that the Bethesda system for reporting of cytopathology is clinically very significant and highly correlates with other investigative modalities and with the histopathological findings.

FNAC is an excellent, safe diagnostic procedure with high degree of accuracy, rapid results and less invasive procedure than a tissue biopsy. It plays a crucial role in the selection of patients for surgery.

\section{REFERENCES}

1. Burch, H. B., Burman, K. D., Reed, H. L., Buckner, L., Raber, T., \& Ownbey, J. L. (1996). Fine needle aspiration of thyroid nodules. Determinants of insufficiency rate and malignancy yield at thyroidectomy. Acta cytologica, 40(6), 1176-1183.

2. Esmaili, H. A., \& Taghipour, H. (2012). Fineneedle aspiration in the diagnosis of thyroid diseases: An appraisal in our institution. ISRN Pathology, 2012.

3. Gupta, M., Gupta, S., \& Gupta, V. B. (2010). Correlation of fine needle aspiration cytology with histopathology in the diagnosis of solitary thyroid nodule. Journal of thyroid research, 2010.

4. Borget, I., Vielh, P., Leboulleux, S., Allyn, M., Iacobelli, S., Schlumberger, M., \& de Pouvourville, G. (2008). Assessment of the cost of fine-needle aspiration cytology as a diagnostic tool in patients with thyroid nodules. American journal of clinical pathology, 129(5), 763-771.

5. Aravinthan, T., Banagala, A. S. K., \& Gamage, K. J. P. K. (2007). Use of fine needle aspiration cytology on thyroid lumps. Galle Med J, 12(1), 257.

6. Godinho-Matos, L., Kocjan, G., \& Kurtz, A. (1992). Contribution of fine needle aspiration cytology to diagnosis and management of thyroid disease. Journal of clinical pathology, 45(5), 391395.

7. Silverman, J. F., West, R. L., Larkin, E. W., Park, H. K., Finley, J. L., Swanson, M. S., \& Fore, W. W. (1986). The role of fine- needle aspiration biopsy in the rapid diagnosis and management of thyroid neoplasm. Cancer, 57(6), 1164-1170.

8. Hawkins, F., Bellido, D., Bernal, C., Rigopoulou, D., Valdepeñas, M. P. R., Lazaro, E., ... \& De Agustin, P. (1987). Fine needle aspiration biopsy in the diagnosis of thyroid cancer and thyroid disease. Cancer, 59(6), 1206-1209.

9. Hall, T. L., Layfield, L. J., Philippe, A., \& Rosenthal, D. L. (1989). Sources of diagnostic error in fine needle aspiration of the thyroid. Cancer, 63(4), 718-725.

10. Gagneten, C. B., Roccatagliata, G., Lowenstein, A., Soto, F., \& Soto, R. (1987). The role of fine needle aspiration biopsy cytology in the evaluation of the clinically solitary thyroid nodule. Acta cytologica, 31(5), 595-598. 